31. Stepanova-Klyuchnikova, G. Ye. (2003). Kazakhstanskiy ALZhIR [Kazakhstan ALZHIR]. Moskva, Malinovka, Astana: Assotsiatsiya zhertv nezakonnykh polit. repressiy.

32. Shumyatskaya, O. Glavnyy ugovor - ne razrevetsya [The Main Agreement Is Not to Burst into Tears]. URL: http://www.novayagazeta.ru/arts/42885.html

33. Epplbaum, E. (2006). GULAG. Pautina Bolshogo terrora [Gulag: A History]. Moskva : Mosk. shkola polit. issledovaniy.

УДК 351.853-025

\title{
ГРОМАДСЬКИЙ КОНТРОЛЬ ДІЯЛЬНОСТІ ПІДПРИЕМСТВ ТОРГІВЛІ, ХАРЧУВАННЯ ТА ПОБУТОВОГО ОБСЛУГОВУВАННЯ: ДЕТАЛІ ПОЛІТИЧНОЇ РЕКОНСТРУКЦІЇ «ВІДЛИГИ»
}

\section{Докашенко Віктор}

У статті розглядаються політичні аспекти сочіальних трансформацій епохи «відлиги». У форматі дискусії доводиться, щңо проблемний розвиток соиіальної сфери в республіиі обумовлювався пріоритетним розвитком виробництва групи «А» перед групою «Б», що первісно зумовлювало їх нерівноправне становище $i$ викликало запрограмоване відставання останньої. Доводиться, щчо пильна увага нової влади до питань сочіальної сфери була продиктована як загостренням політичного протистояння з прихильниками сталінського режиму, так і необхідністю пристосування політичної системи СРСР до умов повоєнного світу. Прочес формування професійними спілками громадського контролю розподіляється дослідником на два етапи. Підкреслюється, що партією було спеціально обрано такий предмет політичного впливу, який міг принести максимальні політичні дивіденди у вигляді підтримки з боку широких верств населення. Це були підприємства торгівлі, громадського харчування та побутового обслуговування населення. Слабко розвинені, вони не могли задовольнити потреб суспільства, а тому найменші позитивні зрушення у иій царині, ставилися владі в заслугу. Зроблено декілька принципових висновків щодо значення громадського контролю. Зокрема стверджується, щзо приведення його в дію значною мірою зумовлювалося необхідністю маскування концептуальних хиб, покладених в основу радянської економіки, а також потребою камуфлювання тоталітарної сутності нової влади, що породжувало ілюзію ї̈ турботи про суспільство. Автор припускається думки, що організований профспілками контроль за сферою торгівлі, харчування та побуту дав змогу зрушити проблему з місия, щзо на певний час $і$ відтермінувало неминучу відставку влади «відлиги». Разом з тим, дослідник наголошує, щя організований 
профспілками контроль являв собою частину концепції радянського менеджменту, спрямованого на розподіл матеріальних благ. Розвиваючи систему громадського контролю професійні спілки підтверджували ленінську концепцію профспілкового руху як «школу комунізму», щзо навчає трудівників управляти державними справами.

Ключові слова: «відлига», громадський контроль, громадське харчування, побутове обслуговування, політична влада, професійні спілки, торгівля.

Сфери торгівлі, громадського харчування та побутового обслуговування населення залишалися проблемою для всього періоду сталінщини. Її витоки лежать у пріоритетності розвитку засобів виробництва перед виробництвом предметів споживання, визначеної радянськими теоретиками за одну із засадничих умов розвитку соціалізму. Новій владній команді на чолі 3 М. С. Хрущовим, яка вибудовувала свою політичну лінію на зовнішньо показовому запереченні сталінізму, з метою послаблення владних амбіцій своїх політичних опонентів, гріх було не поставити їм у провину недорозвиненість цієї важливої ланки людського буття. Такий політичний крок був цілком виправданим. Фінансовані за залишковим принципом, усі галузі економіки, що замикалися безпосередньо на людині, знаходилися у вкрай жалюгідному стані. Це породжувало дефіцит товарів та послуг, і таким чином, значно підвищувало значущість їх розподілу. $\mathrm{y}$ свідомості суспільства, на нашу думку, розподіл товарів знаходився навіть вище, аніж саме їх виробництво, що легко знаходить своє пояснення. Кожний окремо взятий член радянської спільноти не відчував себе власником засобів виробництва, оскільки вони були віддалені від нього системою бюрократичних перепон. Зате кожен 3 них гостро відчував нестачу чи взагалі відсутність вже вироблених матеріальних благ на повсякденному, побутовому рівні. Тому останне для нього мало більшу вагу, ніж засоби виробництва, на яких вони вироблялися i якими вони володіли лише формально. I хоч К. Маркс у «Критиці Готської програми» й застерігав, що було б помилкою бачити суть справи лише у «так званому розподілі» (курсив видання. - В. Д.) [12, 20], але радянські реалії виявилися іншими. Питання розподілу в них набули особливої, політичної ваги. По суті, вони перетворилися в інструмент зміцнення та утримання влади. Тому успіх політиків, що розпочали експеримент, який отримав назву «відлиги», фактично залежав від того, наскільки справедливою виявиться запропонована нею система контролю за розміщенням вироблених благ.

Владна команда, як на нашу думку, в умовах запропонованої економічної моделі розвитку країни знайшла єдиний правильний вихід. Вона доручила організацію та здійснення контролю за цією важливою справою професійним спілкам. 3 політичної точки зору, це було точне і бездоганне рішення. 3 одного боку, на профспілки перекладалась відповідальність за 
будь-які недоліки за його здійснення, а з іншого, - контрольовані партією влади, вони були абсолютно прогнозованими в своїх діях. При цьому принагідно зазначимо, що передача профспілкам цієї важливої функції не була відкриттям нової влади. Ще згідно зі сталінським статутом, прийнятим у 1949 р., вони зобов'язувалися здійснювати «масовий контроль над виконанням планів житлового і культурно-побутового будівництва, роботою їдалень, магазинів, комунально-побутових підприємств i, навіть, міського транспорту $[37,8]$. Отже, в нових умовах залишилося лише закцентувати на цих питаннях увагу. Тому цілком логічним $є$ те, що в Постанові Грудневого (1957 р.) пленуму ЦК, який розглядав нову перспективу профспілок, наголошувалося на тому, що 3-поміж багатьох питань свого впливу вони повинні були взяти під свій неослабний контроль ще й діяльність підприємств торгівлі та громадського харчування [13, 222].

Отже, в проблемі організації контролю за діяльністю підприємств торгівлі, громадського харчування та побуту тісно переплелися аспекти політичного життя, які суттєво впливали на зміцнення владних позицій нової команди, i питання організаційні, що безпосередньо входили до іï компетенцій. 3 огляду на зазначене, поставлена проблема $\epsilon$ актуальною для наукових студіювань. По суті, вона дозволяє наукове простеження політичного і господарсько-організаторського векторів суспільного життя, що не може не викликати наукового інтересу. Значною мірою зазначене актуалізується також станом сучасного розподілу матеріальних благ в Україні, який супроводжується непримиримою i, схоже, такою ж мірою безуспішною боротьбою з корупцією, витоки якої, вочевидь, слід шукати ще на попередніх стадіях історичного розвою.

Втім, незважаючи на науковий інтерес та реальну практичну значущість, поставлена проблема, як і проблема діяльності найчисельнішої громадської організації, врешті, як і всі події, що охоплюються хронологічними межами «відлиги», ще не стали предметом цілісного історичного дослідження. На це $\epsilon$ свої причини, що вимагають окремого історіографічного аналізу. Стосовно ж проблеми, що сформульована нами, то найближче до неї стоїть спільна монографія в авторстві В. К. Барана та В. М. Даниленка «Україна в умовах системної кризи (1946-1980-і pp.)». I хоч зараз, майже через два десятиліття, від часу іiі видання, ми не можемо погодитися 3 низкою іiі положень (наприклад, назва монографії допускає можливість некризового розвитку радянської системи), вона і досі залишається в Україні чи не єдиним комплексним дослідженням предмету нашого аналізу [1].

Певною мірою доповнює іiі розкриття й наша публікація п'ятирічної давнини, в якій у політичному контексті аналізується профспілкове «Положення про комісію громадського контролю за роботою торгу ВРПу, [відділ робітничого постачання. - B.Д.] тресту їдальнь, продпостачі [продовольчого постачання. - В. Д.]» [4]. На жаль, готуючи ту статтю до друку, автор ще не розумів, що цілісне уявлення про вплив проблеми на 
політичне життя країни може дати лише ії̈ комплексне дослідження через формат вдосконалення розподілу вироблених благ та побутових послуг. Зараз зрозуміло, що ӥй вочевидь бракує масштабності в узагальненнях, що, власне, сподіваємося, вдасться компенсувати цим доробком.

На завершення огляду літератури назвемо такий важливий напрям історичних досліджень, як вивчення повсякденного буття, що логічно вписується в означене коло питань. Належне у цій царині, безперечно, слід віддати Л. В. Ковпак [7]. Разом $з$ тим, не можна не визнати оригінальності публіцистичного видання В. В. Похльобкіна «Кухня века», яке безсумнівно можна вважати яскравою ілюстрацією до поставленої нами проблеми [28]. I хоч погодитися з багатьма політичними твердженнями автора через його яскраво виражену упередженість до всього українського, сконцентровану переважно в підрозділі «Україна», ми не можемо, втім, акценти, поставлені ним на різного роду «кулінарних витребеньках», дозволяють простежити їх значення для політичного життя епохи «відлиги» та осягнути всю глибину прірви, що утворилася між політичною елітою того часу та пересічними громадянами.

Метою статті є дослідження політичних мотивів формування масового громадського контролю за діяльністю підприємств торгівлі, громадського харчування та побутового обслуговування, здійснюваного під керівництвом професійних спілок. У зв'язку з цим планується визначити їх місце у зміцненні політичних позицій владної команди, а також з'ясувати роль структур цієї громадської організації в пристосуванні радянської політичної системи до умов повоєнного світу. 3 цією метою планується простежити етапи формування громадського контролю та визначити його політичне значення для влади «відлиги». Оскільки в статті передбачається простеження історичних деталей, що виходять 3 політичного ряду історії, вважаємо цілком доцільним здійснення іiї підготовки на основі форм та методів, характерних для політичної історії.

Перш ніж перейти до викладу власної позиції та аргументів, зауважимо, що хрущовська команда була не першою, хто намагався використати нерозвинутість соціальної сфери в своїх політичних інтересах. Першість, вочевидь, слід віддати Голові Ради Міністрів СРСР Г. М. Маленкову, котрий, виступаючи 8 серпня 1953 р. на сесії Верховної Ради СРСР, усупереч офіційній партійній позиції заявив: «На базі досягнутих успіхів у розвитку важкої промисловості у нас $\epsilon$ всі умови для того, щоб організувати стрімке піднесення предметів народного споживання» $[11,8]$. Інша річ, що партійні «побратими» негайно скористалися цією ідеологічною помилкою і звинуватили його в усіх тяжких злочинах, невдовзі звільнивши його 3 високої посади. Опосередковано політичний намір Голови Ради Міністрів СРСР підтверджує відомий дослідник «відлиги» О. В. Пижиков. 3 посиланням на архів Президента Російської федерації, він наводить слова М. С. Хрущова, який стверджував, що Г. М. Маленков витратив 250-300 т золота на 
придбання продуктів харчування $[31,153]$. Якщо це дійсно так, то політичні наміри - очевидні. Інша річ, що політичні плоди на вкрай слабкій соціальній ниві тоді зібрали зовсім інші люди.

Отже, якби не політичні амбіції Г. М. Маленкова, навряд чи він наважився $б$ на такий нерозсудливий крок. Адже він не міг не розуміти, що славнозвісна пріоритетність виготовлення засобів виробництва була наріжним каменем у теоретичних засадах розбудови соціалізму. Та й сумний досвід дискусії з цього питання залишався на слуху. Ще не стерлася в пам'яті повоєнна дискусія 3 економічних питань, розпочата Й. В. Сталіним у «Економічних проблемах соціалізму в СРСР». Не забулося й те, як жорстоко «вождь» обійшовся 3 працівником Держплану, уродженцем Полтавщини Л. Д. Ярошенком, який наївно повірив у іiі щирість та демократичність. Він наважився не тільки піддати сумніву постулат про пріоритетність розвитку промисловості групи «А» перед групою «Б», а й просив доручити йому підготовку підручника 3 політекономії соціалізму, що базувався б на власному баченні проблеми. Відповідь його високого візаві була просто вбивчою і в прямому, і в переносному сенсах. Щоправда, до фізичного вбивства справа не дійшла, але звільнення з в'язниці відбулося вже після смерті Й. В. Сталіна. У переносному сенсі, мається на увазі рівень аргументованості сталінських, так би мовити, наукових позицій. У запалі дискусії він, зокрема, заявив: «Переважаюче зростання засобів виробництва необхідне не тільки тому, що воно повинно забезпечити обладнанням як власні підприємства, так і підприємства всіх інших галузей, але й тому, що без нього неможливе здійснення розширеного виробництва» [36, 66-67]. Ось так 3 безпосередністю диктатора від науки: «неможливе» і все, без будь-яких пояснень і застережень. Світовий досвід зворотного розвитку навіть не розглядався.

Отже, для того щоб підприємства торгівлі, громадського харчування та побуту надавали принципово інший, якісний та бездефіцитний перелік товарів та послуг, а відтак власники могли отримати політичний зиск, їм слід було внести поправку до теоретичних догматів сталінізму про пріоритетність розвитку промисловості групи «А» перед групою «Б». Чи спромоглися це зробити нові очільники держави? Питання, імовірно, риторичне. Це повністю підтверджує нижченаведена таблиця, складена на основі статистичних збірників «Народне господарство України» за 1959, 1961, 1963 та 1964 pp. [32]. 
Таблиция 1

Питома вага засобів виробництва (група «А») і предметів споживання (група «Б») у валовій продукції промисловості

\begin{tabular}{|c|c|c|c|c|c|}
\hline \multirow{2}{*}{ Роки } & \multicolumn{5}{|c|}{ У тому числі: } \\
\cline { 2 - 6 } & вся продукція & група «А» & $\begin{array}{c}\text { у \% до } \\
\text { попереднього } \\
\text { року (+-) }\end{array}$ & група «Б» & $\begin{array}{c}\text { у \% до } \\
\text { попереднього } \\
\text { року (+-) }\end{array}$ \\
\hline 1956 & 100 & 70,0 & --- & 30,0 & --- \\
\hline 1958 & 100 & 70,6 & $+0,6$ & 29,4 & $-0,6$ \\
\hline 1959 & 100 & 70,5 & $-0,1$ & 29,5 & +1 \\
\hline 1960 & 100 & 71,4 & $+0,9$ & 28,6 & $-0,9$ \\
\hline 1961 & 100 & 71,8 & $+0,4$ & 28,2 & $-0,4$ \\
\hline 1962 & 100 & 72,5 & $+0,7$ & 27,5 & $-0,7$ \\
\hline 1963 & 100 & 73,3 & $+0,8$ & 27,5 & 0 \\
\hline 1964 & 100 & 73,5 & $+0,2$ & 26,7 & $-0,8$ \\
\hline
\end{tabular}

Зведені в таблицю дані дають можливість простежити динаміку питомої ваги виготовлення засобів виробництва та предметів споживання у валовій продукції промисловості з 1956 по 1964 рр. Нам не вдалося відшукати дані лише за 1957 р., що, однак, суттєво не впливає на з'ясування загальної тенденції процесу. Таким чином за дев'ятирічний період хрущовського панування незначне зниження $(0,1 \%)$ промислової продукції групи «А» в питомій вазі валової продукції мало місце лише в 1959 р. Тоді ж як питома вага продукції групи «Б» за цей же час спостерігалося лише один раз, в 1959 p., і продемонструвала зростання на $1 \%$. У 1963 р. вона залишилася на рівні попереднього року. В усі інші роки чітко вимальовується тенденція іiі щорічного зниження. Крім того, якщо питома вага товарів групи «Б» у 1956 р. складала 42,8 \% товарів від групи «А», то упродовж дев'ятирічного циклу вона поступово зменшилася до 36,3 \%. Тобто, товари групи «Б» в питомій вазі товарів групи «А» скоротилися за цей час на $6,5 \%$.

Для досліджуваної проблеми наведене має першочергове значення, оскільки, по-перше, спростовує твердження деяких авторів, що декларована М. С. Хрущовим «соціалізація» передбачала зміни в співвідношенні темпів розвитку промисловості «групи «А» та «групи Б». Важливим $\epsilon$ й те, що висновок, зроблений на основі таблиці, не підтверджує судження цих дослідників про те, що «період другої половини 1950-х - середини 1960-х років змінив структуру економіки та баланс між галузями промисловості, що дозволило сформувати основи для суспільства споживацького типу» [3, 12]. До речі, цей підхід повністю спростовує і головний ініціатор «відлиги». «Щоб мати достатню кількість засобів споживання, потрібні засоби виробництва...», - заявив М. С. Хрущов на XXI з’їзді КПРС [5, 54]. 3 точки зору методології економічного розвитку, наведена цитата нічим не відрізняється від сталінської, запропонованої у якості аргументу дещо вище. 
По-друге, якщо визнати справедливість даних, то, очевидно, і розвиток соціальної сфери не може бути повноцінним, а відтак витоки «соціалізації», на нашу думку, слід шукати в іншому ареалі.

Автор знаходить їх у політичному полі, що дає йому підстави припуститися думки про іi первісне політичне призначення, спрямоване на зміцнення влади, яка все більше піддавалася нищівній критиці $з$ боку вчорашніх соратників нового вождя. Якщо виходити 3 того, що соціальна сфера тривалий час була найслабшою ланкою сталінського правління, то цей чинник був чи не основним у переліку тих, що робили позиції влади вкрай вразливими. Тому вже навіть мінімальні позитивні зрушення в іiі царині могли надати новим очільникам значних політичних дивідендів. Використовуючи цю слабкість, вони могли досить легко, попри стійкий синдром страху, прищеплений сталінізмом суспільству, знайти в нього підтримку, а значить, і отримати необхідний рівень його прихильності. Остання відразу нівелювала всі зусилля старої когорти урядовців та партійних чиновників, спрямованих на дискредитацію нової влади.

Ця, не позбавлена логіки точка зору, видається досить привабливою ще й тому, що керівники СРСР вже мали подібний досвід використання соціальних проектів. Так, у 1930 р., впритул зіткнувшись з результатами колективізації і намагаючись зберегти своє політичне реноме, Рада Народних Комісарів прийняла постанову «Про розвиток громадського харчування». За декілька років пропонувалося перевести на організоване харчування приблизно $50 \%$ населення великих промислових міст, що давало змогу не лише забезпечити продуктами харчування робітників, а й значно раціональніше та економніше використовувати вбогий запас харчів. Останнє, 3 огляду на те, що саме партія була ініціатором колективізації, переводить проблему 3 питань економічної стратегії в суто політичну площину. Обов'язкові умови здійснення цього масштабного проекту, як зазначалося в документі, могли набрати рис реальності лише за «активної участі в цій роботі місцевих рад, професійних спілок, широких верств трудящих, особливо жінок» [20]. Рік поспіль - нова Постанова. Громадське харчування Москви, Ленінграда, Уралу та Донбасу виокремлювалося 3 системи споживчої кооперації. Тут запроваджувалися державні трести громадського харчування, що працювали на госпрозрахункових засадах [23], що, власне, теж не було позбавлене політичного сенсу, адже саме робітничий клас був опорою радянської влади, у зв'язку з чим стан харчування та його ціна з суто побутового фактору перевтілювався в політичний.

У повоєнний період, у найбільш відповідальний та гострий момент, проблемами соціальної сфери скористалася Компартія України, яка в кінці червня 1953 р. прийняла Постанову Пленуму «Про збільшення виробництва, підвищення якості товарів широкого вжитку і заходи із забезпечення покращання побутового обслуговування трудящих». Теж не випадкове рішення, як не випадкова й дата його прийняття, адже протистояння 
претендентів на владу досягло на цей час свого апогею i на якийсь час завмерло на піку своєї невизначеності. До рішення липневого (1953р.) Пленуму ЦК КПРС залишалося близько тижня.

Для профспілок Української РСР воно виявилося надзвичайно важливим, оскільки вперше вищий керівний партійний орган визнав основою діяльності наймасовішої громадської організації у царині виробництва й реалізації не засоби виробництва, а предмети споживання. У цьому рішенні серед значної кількості традиційних настанов, які можна було б використати у будь-якій галузі, вирізняється завдання посилення громадського контролю «за діяльністю підприємств побутового обслуговування, торгівлі та громадського харчування» [22, 475]. По суті, Пленум ЦК вперше нагадав профспілкам про необхідність виконання не лише тих повноважень, що стосувалася підприємств групи «А» з організацією змагальності, новаторства, передових методів праці, а й тих, що були включені до групи «Б». При цьому зазначимо, що профспілки ще у першому повоєнному Статуті самі виявили готовність займатися цією справою. Складається враження, що вони просто чекали на команду свого політичного патрона, щоб тут же приступити до ії виконання. У їхньому основоположному документі зразка 1949 р. було записано, що вони здійснюють «масовий контроль... над роботою їдалень, магазинів, комунально-побутових підприємств і міського транспорту» $[37,8]$.

ЦК КПРС звернув увагу на ці питання значно пізніше, але, зазначимо, знову ж таки в найбільш відповідальний для влади момент. Ледве встиг закінчити свою роботу ХХ з’їзд КПРС з його ідеями десталінізації та «соціалізації», як вже 1 березня ЦК КПРС прийняв Постанову «Про заходи 3 покращання роботи підприємств громадського харчування», якою дав об’єктивну характеристику стану справ у галузі. Оцінюючи значення Постанови, вже згадуваний у цій статті В. В. Похльобкін, писав, що в ній «з усією силою підкреслювалася політична вага громадського харчування, що було правильним, але, як виявилося пізніше, не дійшло до свідомості людей і залишилося лише фразою, яка була зрозумілою хіба що ініціаторам і творцям цієї постанови, але на яку зовсім не звернули уваги їі основні виконавціпрацівники кулінарного фронту». Втім, автор цитати звертає увагу лише на один бік політичного питання: трансформацію громадського харчування за зразком західного, який вже тоді дозволяв сім'ям не переобтяжуватися домашнім приготуванням їжі. І вигідніше, і корисніше, і смачніше це робили заклади харчування, що змінювало всю парадигму життя та використання вільного часу.

Нами політичний бік питання розглядається дещо з іншого ракурсу. Ми аналізуємо його як превентивний захід, націлений на те, щоб не допустити можливого вияву невдоволення з боку широких верств населення, що було цілком вірогідним у зв'язку із засудженням культу особи Й. В. Сталіна. 3 огляду на тривалість сталінського правління та методів його пропаганди, такий варіант розвитку подій виключати не можна. Вочевидь, з цієї причини 
до пропагандистської термінології й включалася соціально-побутова лексика, яка переводила увагу громадян з питань політичних на не менш гострі питання соціальні. Крім того, відсутність необхідної мережі їдалень, несмачна їжа, вкрай бідне меню, розкрадання продуктів i їх недостатня кількість у справах, некваліфікованість кухарів, грубість і нечемність персоналу, врешті, антисанітарні умови, - все це були чинники, які формували невдоволення суспільства не лише громадським харчуванням, а й владою... Утім, весь негатив у цьому випадку переводився на попередників.

Зрозуміло, що названа Постанова ЦК спрямовувалась на формування позитивного іміджу нової влади. В ній не тільки речі називалися своїми іменами, а й ставилися завдання кардинального виправлення ситуації. Врешті, намічався покроковий план ліквідації недоліків. Звичайно, за цих обставин нова влада могла викликати до себе в суспільстві лише прихильне ставлення. Ця прихильність і була тією бажаною формою підтримки, яка допомагала політичній владі «відлиги» подолати спротив ортодоксальних сталіністів. До виходу в світ постанови ЦК «Про подолання культу особи та його наслідків», яка поставить крапку в цій боротьбі, залишалося менше чотирьох місяців.

Не менш важливе значення для визначення політичної складової Постанови мало й те, що нею визначався механізм контролю за іiі виконанням. Партія запропонувала профспілкам за допомогою організації народного контролю у сфері громадського харчування домогтися піднесення якості виготовленої продукції, та зробити іiі, за словами В.В.Похльобкіна, «потрібним, необхідним, невід'ємним елементом радянського побуту». Як показав час, виконати її накреслення повністю не вдалося. Причину невдачі названий автор вбачає в індиферентній та формальній позиції профспілок [28]. Ми з цим не погоджуємося, адже це точка зору не розкриває причини невдачі. По-перше, їх слід шукати в сиупені пріорітетності промисловості групи «А» перед групою «Б». По-друге, хибною була сама ідея внесення до їх Статуту функції контролю за цими галузями. Допускаючи це, ми керуємося звичайною буденною логікою, за якої здійснення контролю зазвичай покладається на осіб, що мають відповідний фах. Тобто здійснення контролю відбувалося на основі аматорства, адже профспілки могли реалізувати його лише на цих засадах. Таким чином здійснення контролю перетворювалося на цікаву політичну гру.

Приймаючи Постанову й зобов'язуючи профспілкові організації здійснювати контроль за діяльністю підприємств громадського харчування, ii укладачі сповна розуміли всю фіктивність цієї вимоги. Громадські контролери, у кращому випадку, могли лише зафіксувати недотримання якихось формальних вимог, таких, скажімо, як чистота скатертин або посуду. Вони могли також перелічити кількість посадочних місць у їдальнях, кафе та ресторанах, але вони, і тут ми повністю погоджуємося з автором кулінарних бестселерів, не могли проконтролювати якість страв, що готуються на 
підприємствах громадського харчування, запропонувати нові технології їх приготування чи урізноманітнити асортимент блюд. Розуміли це укладачі Постанови? Переконані, що так.

Якщо виходити з того, що сама Постанова ЦК та Ради Міністрів СРСР мала більш політичне значення, ніж практичне, то такий характер повинен мати і масовий контроль професійних спілок, адже саме він наповнював його політичним змістом. Тому, чим гучніші заходи проводилися громадською організацією, тим більшого політичного резонансу вони набували. За приклад, візьмемо Пленум Укрпрофради, який проходив з порядком денним: «Про виконання Постанови ЦК КПРС і Ради Міністрів СРСР від 1 березня 1956 р.» в середині листопада того ж року. Звернімо увагу, що 3 доповідями на ньому мали виступити керівники Міністерства торгівлі, Укоопспілки та Республіканського комітету працівників споживчої кооперації [9, 134]. 3 політичної точки зору, було вигідним те, що на Пленум було запрошено водночас три керівники, які опікуються цією справою, але, з практичної, навряд чи рішення цього зібрання могли суттєво вплинути на якість, як того вимагала Постанова Президії ВЦРПС від 7 квітня 1956 р. У ній, зокрема, зазначалося, що «Громадський контроль повинен спрямовуватися на посилення боротьби за високу культуру торгівлі, викорінення недоліків у обслуговуванні трудящих, на покращання якості харчування, здешевлення іiі вартості та зразкову організацію роботи їдалень».

Під час детального ознайомлення з цим документом відразу ж кидається у вічі те, що у цьому всю відповідальність за роботу підприємств торгівлі та харчування було перенесене 3 плечей владних структур на безпосередніх виконавців - керівників трестів їдалень, керівників відділів робітничого постачання (ВРП), торгів, керівників закладів харчування. Справа в тому, що, згідно з Постановою, названі категорії працівників торгівлі та харчування повинні були відзвітуватися про свою роботу найближчим часом на загальних зборах або на конференції робітників підприємств і установ. Навіть поверховий аналіз переліку чеснот громадського харчування нового зразка, який пропонувала Постанова Президії ВЦРПС, формує уявлення про те, що в усіх його вадах винна зазначена категорія працівників, а не система, що їх породила. Як же інакше можна розцінити іiі вимогу щодо створення системи масового контролю за цими підприємствами? Зокрема, іiі пункт 3 передбачав «установити повсякденний контроль за роботою підприємств торгівлі та громадського харчування, для чого обрати необхідну кількість громадських контролерів із розрахунку приблизно 15-20 осіб на їдальню та 10-12 на магазин». Останні повинні обов'язково бути з числа найбільш активних робітників та службовців [27, 620-623]. Однозначно зазначимо, що в 1958 р. середня кількість робочих місць в одному магазині складала 1,86 [6].

Оскільки основна частина політичного резонансу здійснювалася на нижчих ланках профспілкової ієрархії, то нагальним завданням вищих профспілкових органів було створення для них необхідної документальної 
бази. Певна частина цих документів вже була підготовлена у перші постсталінські роки, і тому вимагала лише свого переформатування в дусі «відлиги». Першим документом, який було адаптовано до нових умов, було «Положення про комісії громадського контролю і громадських контролерів фабрично-заводського (місцевого) комітету профспілки за роботою підприємств торгівлі та громадського харчування», затвердженого Президією ВЦРПС у березні 1957 р., яке замінило аналогічне Положення, затверджене Секретаріатом ВЦРПС у червні 1948 р. Склад комісії ФЗМК міг коливатися в діапазоні від 5 до 21 особи. Зміст іiї роботи був визначений 11 пунктами, кожен з яких, у свою чергу, поділявся на дрібніші. За нашими підрахунками, загальна їх кількість перевищувала 40 напрямів роботи. Громадських контролерів було розділено на тих, що контролювали магазини, лавки, палатки та ларьки, і тих, хто опікувалися їдальнями, чайними, закусочними i буфетами. У випадку виявлення порушень контролер мав скласти акт й передати його до фабзавкому для надсилання за належністю [27].

У липні 1958 р. Президією ВЦРПС було прийнято нове Положення, яким обласні та республіканські ради профспілок утворювали по кожному торгу, тресту їдалень, відділу робітничого постачання і ПРОДПОСТАЧі комісії громадського контролю. Вони складалися 3 представників ФЗМК провідних підприємств, будов, установ та навчальних закладів, що обслуговувалися підрозділами названих торгівельних об'єднань. Ця форма контролю охоплювала вищу ланку торговельних установ. У своїй роботі вона спиралася на аналогічні комісії ФЗМК та їхніх контролерів, але функції їх були значно масштабнішими. Вони розглядали питання розвитку, спеціалізації, розміщення мережі підприємств торгівлі та харчування, перевіряли правильність розподілу товарів по магазинах, стежили за забезпеченням безперебійного завозу товарів, перевіряли виконання плану товарообігу, перевіряли питання забезпечення магазинів і їдалень необхідною технікою тощо. Відповідно до змісту роботи, комісії мали і права. Вони могли проводити перевірки та позапланові ревізії, вимагати певних пояснень від керівників цих об'єднань, приймати скарги на якість обслуговування [26]. Партійні органи ретельно пильнували роботу спілок у цьому напрямі. Харківський обласний комітет партії, наприклад, заслухав звіт обласної ради профспілок про виконання ним рішень ХХ з'їзду КПРС (грудень 1958 р.). Під час звіту на засіданні бюро обкому партії, облпрофрада (ОРП) включила до своєї інформації не лише власну «звитягу» дво- трирічної давнини, як того вимагав порядок денний, а й власну реакцію на ще «свіже» Положення ВЦРПС.

Формування системи масового контролю діяльності підприємств торгівлі та громадського харчування профспілки завершилося у вересні 1958 р. прийняттям Постанови ВЦРПС «Про контроль профспілок за роботою оптових баз», якою на них поширювалися права комісії громадського контролю за роботою торгу, тресту їдалень, відділу робітничого постачання..., від 
11 липня 1958 р. [16]. Зазначимо, що територіальні органи профспілок реагували на неї досить жваво. Та ж Харківська облпрофрада до грудня вже встигла сформувати 9 таких комісій. Відночас зазначимо, що тією ж Постановою було затверджено Директивного листа ВЦРПС та Міністерства торгівлі СРСР, який легітимізував контроль профспілок за роботою оптових баз [15]. Усі інші підприємства торгівлі та громадського харчування керувалися наказом Міністра торгівлі СРСР від 30 вересня 1953 р. [18].

Таким чином, станом на кінець 1958 р. професійними спілками було завершено процес формування масового громадського контролю за діяльністю підприємств торгівлі та громадського харчування. Така інтенсивність у роботі була викликана зовсім не дефіцитом продуктів харчування, як можна було зрозуміти. Справа в тому, що завдяки заходам, спрямованим М. С. Хрущовим на підтримку індивідуальних підсобних господарств, вони перетворилися на надійне джерело постачання продуктів, що повною мірою підтверджує обсяг продажу продуктів харчування на так званих колгоспних ринках. У 1958 р. реалізація продукції на них досягла своєї вершини за весь час «відлиги». Навіть офіційна статистика, яка, м'яко кажучи, не приділяла багато уваги підсобним господарствам робітників і службовців, змушена була констатувати, що в 1958 р. на ринках 53 міст УРСР було реалізовано 86876 т м'яса, сала та птиці, 54970 тис. л молока, 298479 млн штук яєць [30,554-555]. Це була суттєва частка забезпечення населення продуктами харчування. Знову ж таки, станом на 1958 р., тобто на час завершення формування тотальної системи контролю за підприємствами торгівлі та харчування, за нашими підрахунками, 85,9 \% курячих яєць, що виробили в усіх видах господарств, були продукцією підсобних господарств, в них же надоювали 49,5 \% молока та вирощували 55 \% м'яса всіх видів [25]. Отже, за рахунок розвитку підсобних господарств, а також за рахунок екстенсивного ведення землеробства, навіть за всіє згубності колгоспно-кооперативної системи господарювання, владі чи не вперше за весь час існування СРСР вдалося утримати під контролем належне забезпечення населення продуктами харчування. Тому організація масового контролю не могла бути вимогою, продиктованою дефіцитом продуктів харчування. Забезпечивши населення їх достатньою кількістю, ініціатори «відлиги», принаймні, до широкого розмаху кукурудзяно-бобової кампанії, мали всі підстави для того, щоб вважати це своєю заслугою, що позначалося на їхньому політичному іміджі.

На його збереження була спрямована робота профспілок у розвитку масового контролю за діяльністю підприємств торгівлі. Причому, вони часто навіть випереджали поставлені завдання. Так, Харківська обласна рада профспілок, звітуючись про виконання XX з'їзду КПРС, рапортувала вищому профспілковому органу республіки, що вона через власну систему навчання підготувала 681 контролера, замість 300 передбачених планом [34, 19]. Серед лідерів у цьому відношенні була й Кіровоградська область, де справі 
контролю навчили 404 особи. За 5 місяців 1959 р. ними було перевірено 4047 підприємств торгівлі та громадського харчування, на 747 з них їм вдалося виявити порушення правил торгівлі (у 18,5\% - В. Д.) Крім того, профспілковими комітетами до Держторгінспекції для вжиття заходів було скеровано 217 актів перевірок [24, 36].

Звичайно, завдяки цьому пресингу владі на місцях вдалося втримувати у певній напрузі працівників торгівлі та громадського харчування. Однак головна місія контролю, з нашої точки зору, належала супровідній функції, без якої забезпечення виконання важливого політичного проекту було б неможливим. Не змінюючи сутності функціонування радянської соціальної сфери, він дозволив максимально мобілізувати зусилля на виконання партійної настанови. Його масовість та всеохоплюваність зробили свою справу. Вдалим, з точки зору інтересів команди М. С. Хрущова, виявилося іiі звернення до соціальної проблеми. Очевидно, відчувши це, вона спробувала повторити це вдруге, і 20 лютого 1959 р. ЦК КПРС і Рада Міністрів СРСР приймають нову Постанову «Про подальший розвиток і покращання громадського харчування», яка являла собою новий крок у його піднесенні. Разом з якісним покращанням низки показників у період з 1958 по 1965 pp. планувалося охопити громадським харчуванням більшість робітників, службовців і учнів. У цьому теж приховувався політичний зміст. Укладачі Постанови цього навіть не приховували. Вже у іiі вступній частині, мотивуючи тим, що в країні розпочато розгорнуте будівництво комунізму, вирішення питань громадського харчування було віднесено укладачами до рангу державних завдань.

Показовим $\epsilon$ те, що їх реалізація, як і три роки поспіль, знову видавалася розробникам можливою лише за участі широкого загалу контролерів, до яких профспілкам рекомендується включити не лише робітників і службовців, але й домогосподарок. Чітко було визначено і основні завдання - домогтися покращання якості та здешевлення вартості харчування, дотримання норм закладки сировини та встановлених цін [14]. Звернімо увагу на те, що всі задачі, поставлені перед профспілковим контролерами, більшою чи меншою мірою стосуються тривіальної боротьби 3 дрібними крадіжками та шахрайством, що, погодимося, не може не викликати скепсису на тлі «масштабного» висновку XXI з'їзду про повну й остаточну перемогу соціалізму в СРСР.

Особливо проблемним було становище в їдальнях МТС та радгоспів. На виправлення ситуації була спрямована спеціальна Постанова Ради Міністрів СРСР від 17 червня 1960 pp. «Про заходи покращання громадського харчування в радгоспах». Позитивним, безперечно, слід визнати те, що в полі зору опинилася проблема громадського харчування в селі, де трудівники МТС та радгоспів особливо потерпали від низького рівня організації громадського харчування. При цьому зазначимо, що в чисельному відношенні ця мережа була розвинена непогано. Так, станом на 1960 р. в радгоспах Української РСР 
функціонувало 1227 підприємств громадського харчування, 3 них 727 перебували у структурі споживчої кооперації. Знайомство з документами, що характеризують реальний стан справ, дозволяє припустити, що тут проблемним був не контроль за ї діяльністю, а навіть елементарне забезпечення їдалень посудом та реманентом. Проблемою тут було все: від забезпечення дезінфікуючими засобами та посудом до мийок з теплою водою i столів 3 гігієнічним покриттям. Тому, коли останні вперше почали 3'являтися у Кримській та Полтавській областях, керівників радгоспів, що придбали цю «дивину», тут же почали ставити за приклад мало не всій республіці.

Отже, якби профспілкові комітети за цих обставин використали хоча б частину своїх контролюючих повноважень, то, за нашим переконанням, їх слід було б закрити відразу ж після відкриття, а ще краще - не відкривати взагалі. Для прикладу наведемо деяку статистику радгоспів Одеського тресту 3 виробництва вин, 3 документами якого нам вдалося детально познайомитися. Тут, практично у кожному радгоспі, діяла їдальня, що давало формальну підставу для гарних звітів, чим безсоромно користувалися i партійні, і профспілкові комітети різних рівнів. У 19 підприємствах їдальні знаходилися на балансі цих сільськогосподарських підприємств, і в своїй переважній більшості вони були для них збитковими. Однак, у кожній 3 них робочкомами було встановлено фіксовану вартість триразового харчування у межах 45-50 копійок (1961р.). Досить часто в таких їдальнях процвітала безгосподарність. У радгоспі імені професора М. О. Ховренка, наприклад, вартість триразового харчування перевищувала 1 карбованець. I це за наявносі дуже бідного меню. Із всього обладнання особи, які здійснювали перевірку, виявили тут лише 1 котел, 1 сковороду, три каструлі та два відра [33, 51-54]. Зауважимо, що середня заробітна плата на той час в Україні складала 63,8 карбованця [35]. Зрозуміло, що за такої низької заробітної плати працівники радгоспів просто не могли собі дозволити харчування в їдальнях навіть за умови приготування в них страв ресторанного гатунку. Тому заклики з боку партійних i профспілкових чиновників регулярно їх відвідувати цілими сім'ями та брати їжу додому весь час перебували в зоні не настійливих побажань.

У той же час на промислових підприємствах, як і раніше, продовжував розкручуватись маховик посилення організованого профспілками контролю за діяльністю підприємств харчування. Вочевидь, намагаючись надати йому новий поштовх, влада розраховувала на нові політичні дивіденди. ЦК Компартії України разом з Радою Міністрів УРСР прийняли Постанову, якою, услід за Постановою КПРС та Ради Міністрів СРСР намагалися далі індустріалізувати їдальні через розвиток фабрик-кухонь, на яких страви готувалися, а далі розвозилися по їдальнях. Кількість останніх була вочевидь недостатньою. Зокрема, в Полтавській, Кримській, Сумській та Чернігівській областях, як зазначалося в Постанові, вона навіть не досягла рівня 1940 p. $\mathrm{He}$ 
можемо сказати, що вона стала якоюсь віхою для профспілкового контролю. Як і в попередній ухвалі, в ній Укрпрофраді ставилося в обов'язок забезпечити «докорінне поліпшення громадського контролю підприємств торгівлі та громадського харчування». Ну, як і завжди, їм також рекомендувалося широко розгорнути соціалістичне змагання між цими закладами $[29,10]$.

Втім, досягти якогось позитивного ефекту від цього контролю та отримати від його результатів якийсь політичний зиск, як це було на першому етапі його розвитку, було неможливо. Справа в тому, що в цей час уже гостро далися взнаки результати вкрай невиваженої аграрної політики М. С. Хрущова. Якщо на етапі становлення контролю наймасовішої організації економічні показники вдалося витягти значною мірою за рахунок підсобного господарства, то на його другому етапі, намагаючись наздогнати та перегнати США по виробництву сільськогосподарської продукції на душу населення, воно було доведене до жалюгідного стану. Намагаючись якомога більше здати державі м'яса, колгоспи та радгоспи здавали на м'ясокомбінати не лише власну худобу, а й ту, що скуповували в населення. У 1960 р. стан справ досяг критичної межі. ЦК КПУ та Рада Міністрів УРСР змушені були підготувати закритого листа до обкомів і райкомів партії, до облвиконкомів та райвиконкомів, а також до первинних парторганізацій. У ньому наводяться основні хиби, допущені у «погоні» за сільським господарством США. I хоча сума збитків у всеукраїнському масштабі в ньому не наводиться, деякі вражаючі висновки з наведених в ньому даних все ж таки зробити можна. Так, за оперативними даними, в Полтавській області за перший квартал чисельність корів зменшилася на 15 тис. голів, у Запорізькій - на 9,1 тис., в Одеській - на 8,8 тис., у Вінницькій - на 7,7 тис., в Сумській - на 6,2 тис. У багатьох районах Сталінської, Житомирської і Хмельницької областей проводять масову закупівлю у колгоспників і тут же забивають іï, здаючи на м'ясо, зазначалося в закритому листі $[10,96]$.

Не кращими були справи і у виробництві товарів широкого вжитку, нестача та низька якість яких суттєво підривали політичний авторитет команди влади. Людям було незрозуміло, чому з перемогою соціалізму не вирішене питання виробництва необхідних у побуті товарів. I це при тому, що в усіх партійних постановах, незважаючи на те, що вони присвячувалися тому ж громадському харчуванню, червоною ниткою проходила ідея всілякого сприяння розширенню їх випуску та покращення їх якості. Втім, ситуація небезпечно загострювалася, про що нам принагідно нагадує вищенаведена таблиця, виводячи нас на методологію економічних засад соціалізму. Очевидно, вона стала настільки небезпечною, що Перший секретар ЦК Компартії України змушений був звернутися з цим питанням до Москви. У своєму листі О. І. Кириченко писав про хиби в плануванні, відсутність матеріальної зацікавленості виробника, ну і, звичайно ж, про надмірну централізацію. Лише на 4 \% товарів, що виготовляються в Україні, 3 гіркотою писав він, ціни визначаються на місці. Не дивно, що 
ціноутворення відбувалося вкрай повільно i, навіть, незграбно. Наприклад, на жіночі чобітки Чернівецької гумово-взуттєвої фабрики Міністерство торгівлі СРСР встановлювало ціни майже півроку $[2,82]$.

Щось подібне спостерігалося і у сфері надання побутових послуг. Вже через місяць після закінчення роботи XXI з'їзду КПРС ЦК КПРС і Рада Міністрів Союзу РСР приймають Постанову «Про заходи покращання побутового обслуговування населення». Ї̈ї політичний характер навіть не приховувався. «Тепер, коли наша країна стала на шлях розгорнутого будівництва комунізму, зазначалося в ній, питання докорінного покращання побутового обслуговування населення набуває особливо важливого значення». I знову ж таки, вирішення цього питання вищим керівним органам країни видався можливим лише під контролем місцевих рад та профспілкових організацій [17]. Своєю Постановою тут же відреагувала ВЦРПС, у якій від підпорядкованих ій структур вимагалося покращити громадський контроль за ліквідацією визначених недоліків [21, 4]. I хоч стосувалося воно підприємств місцевої промисловості Російської Федерації, через циркулярний характер документів вищого профспілкового органу воно рівною мірою впливало й на профспілки України.

Названа Постанова ЦК та Ради Міністрів СРСР була останньою в час «відлиги», в якій розглядалися проблеми соціально-побутової сфери. Наскільки вона та їі попередниці були ефективними і необхідними? В умовах суспільної власності на засоби виробництва, очевидно, так. 3 точки ж зору цивілізованого розвитку економіки, вони виглядають як щось викопне, оскільки в їх основу закладалось не ринкове, а командне начало, чого економічний розвій на дух не переносить. Про їхню ефективність можна говорити хіба що у кількісному вимірі. Досить цікаві дані на цей рахунок наводяться у статистичному збірнику «Народне господарство Української РСР» за 1961 i 1964 pp. Так, з 1955 р. по 1964 р. кількість підприємств громадського харчування зросла майже на третину, а число підприємств торгівлі збільшилося 399639 до 138045 , тобто на 27,8\%. Визначити динаміку зростання підприємств побутового обслуговування досить важко, оскільки офіційна статистика 3 цього питання в Україні до широкого загалу не доходила. Навіть загальносоюзний статистичний збірник «Народное хозяйство СССР» вводить ії в обіг лише з 1964 р. Отже, станом на цей рік у республіці налічувалося 24900 майстерень та ательє, з них 12,2 тис. - у сільській місцевості. У них працювало понад 144 тис. осіб, які виконали робіт та послуг на 181,7 млн карбованців. Цифри виглядають досить обнадійливими, позаяк на один район (в УРСР на той час налічувалось 394 сільських і 83 міських райони) припадало в середньому 52 побутових підприємства.

Наведені статистичні дані дають підставу для того, щоб визнати суттєве зростання кількості підприємств торгівлі, громадського харчування та побутового обслуговування населення, які знаходилися в сфері контролю найчисельнішої громадської організації. Відтак, є всі підстави стверджувати 
про поліпшення побутового стану суспільства, а тому цілком логічно можна припустити позитивний вплив цих процесів на політичний престиж влади, яка, власне, ці процеси й ініціювала. Це значить, що партією влади було абсолютно точно визначено предмет свого впливу, який дозволив їй забезпечити максимально високі політичні дивіденди. Значною мірою цьому сприяла i правильно обрана тактика їх отримання - спільні постанови ЦК КПРС та Ради Міністрів СРСР. Останніми визначалися найслабші місця побутового ареалу та пропонувалися заходи, які допомагали їх хоч якоюсь мірою осучаснити. Вже сам факт їх підготовки невдовзі після розвінчання культу особи, а також безпосередньо у ході вироблення стратегії та тактики «відлиги», прогнозовано виводив питання торгівлі, громадського харчування та побуту у політичну площину. Продовження цього процесу було стимульоване вочевидь передчасним висновком XXI з'їзду КПРС про повну і остаточну перемогу соціалізму СРСР. Непродуктивність всієї соціальної ниви дискредитувала партійну ідею, яка явно обігнала радянські реалії. 3 цієї точки зору, спільні постанови партії та уряду були засобом підтягування зазначених галузей до рівня вже оприлюднених висновків.

Інструментом вирішення цього завдання була організована професійними спілками система масового контролю за діяльністю названих галузей, який хронологічно представляється можливим розділити на два етапи. Перший - 31956 р. по 1958 р., обумовлювався боротьбою нової влади 3 залишками ортодоксального сталінізму та супроводжувався організацією системи масового контролю аж до повної ії розбудови. Другий, з 1959 р. по 1964 р., був викликаний передчасним висновком XXI з'їзду, а також різким погіршенням соціального стану трудівників, що відверто йому дисонувало. Ця обставина змушувала спрямовувати вістря громадського контролю на реалізацію партійних постулатів, прямо чи опосередковано пов'язаних 3 останніми установками партії влади. У реальному вимірі він більшою мірою був націлений не на якісні зрушення в названих галузях, а на те, щоб переконати весь світ, включаючи й власну спільноту, в здатності радянської суспільно-економічної системи до позитивних трансформацій.

Штучне привнесення до профспілкового середовища функції контролю переслідувало триєдину мету. По-перше, він був покликаний приховати концептуальні хиби, закладені в основи радянської економіки, що викликали хронічне відставання соціальної сфери, унеможливлюючи іiі стабільний розвиток. По-друге, контроль громадської організації за соціальним сектором маскував тоталітарну сутність політики нової влади, породжуючи в радянської спільноти ілюзію турботи про неї у вигляді корекції економічного розвою. Ї̈і наслідком стала наївна віра переважної більшості суспільства в те, що за допомогою ретельного контролю громадськості можна кардинально змінити існуючий стан речей, не чіпаючи при цьому його фундаментальних засад. По-третє, контроль громадськості сприяв зміцненню політичного 
авторитету влади. Не виключено, що, якби не ця далекоглядна політика влади, відставка команди «відлиги» могла статися значно раніше.

Нарешті, за допомогою громадського контролю створювалася ілюзія участі широких верств населення в управлінні державними справами. За великим рахунком, такий підхід був складовою концепції радянського менеджменту, який вибудовувався на тому, що управляти державою зможе кожний, але цьому треба лише навчитися. У зв'язку з цим В. І. Ленін і писав, що будь-який робітник і будь-яка кухарка не здатні зараз же вступити в управління державою, але їх можуть навчити цьому свідомі робітники і солдати. Їх він закликав долучитися до цього процесу негайно, навчаючи цьому всіх трудящих, всю бідноту [8, 315]. Не будемо спростовувати зараз непорушну істину, що однієї «свідомості» тут, мабуть, все ж таки замало. Втім принагідно зазначимо, що професійні спілки, залучаючи тисячі робітників і службовців до контролю за діяльністю підприємств торгівлі, харчування та побуту, намагалися на практиці втілити цю ідею в життя, тим самим позиціонуючи свою організацію як «школу комунізму».

Громадський контроль, організований профспілками, розглядається дослідником лише як частина політичної програми «соціалізації», проголошеної XX з'їдом, що включала й інші масштабні питання соціального значення. Тому перспектива розробки проблеми, на нашу думку, криється в дослідженні таких іiі складових, як скорочення робочого дня, підвищення заробітної плати, пенсійна реформа, вдосконалення виплат 3 фонду соціального страхування тощо.

\begin{abstract}
The article examines political aspects of social transformations of the «Thaw» period. It is proved by means of discussion that the problematic development of social sphere in the republic was made conditional upon priority development of group "A» production before group «B», which, first of all, put them into unequal conditions and caused a programmed lagging of the latter. It is proved that great attention of the new government to the problems of the social sphere was dictated as by the aggravation of the political confrontation with the supporters of the Stalin regime as by the necessity of adaptation of the USSR's political system to the conditions of the post-war world. The process of formation by the trade unions of civilian control of its character and political conditions is divided by the researcher into two phases. It is being stressed that the governing party had unmistakably selected the object of political influence which could bring highest possible political dividends in the form of its support by various layers of the population. Those were business, public catering and domestic service enterprises. Being poorly developed, they could not satisfy the needs of the society. Also several principal conclusion as to the importance of the civilian control have been made. The author assumes that it was brought into practice with the aim of covering conceptual mistakes embedded into the basis of the Soviet economy and
\end{abstract}


camouflaging the totalitarian nature of the new power therefore generating an illusion of its concern about the society. The author thinks that organized by the trade unions control over the spheres of trade, catering and domestic care provided a possibility to a start of removing the problem, which is, for a period of time, postponed the inevitable dismissal of the "Thaw» government. At the same time the author underlines that organized by the trade unions control presented a part of the concept of Soviet management. While developing it, the trade unions positioned themselves as «the school of Communism» which teaches the workers to manage state affairs.

Key words: "Thaw», civilian control, public catering, domestic service, political power, trade unions, trade.

\section{Аннотация}

B статье рассматриваются политические аспекты соииальных трансформачий в эпоху «оттепели». В формате дискуссии доказывается, что проблемное развитие сочиальной сферы в республике было обусловлено приоритетным развитием производства группь «А» перед группой «Б», что уже изначально ставило их в неравноправное положение и вызывало запрограммированное отставание последней. Утверждается, что пристальное внимание новой власти $\kappa$ вопросам сочиальной сферы было продиктовано как обострением политического противостояния со сторонниками сталинского режима, так и необходимостью приспособления политической системы СССР к поствоенным условиям мира. Прочесс формирования профессиональными союзами общественного контроля исследователем разделяется на два этапа. Подчёркивается, что партия власти безошибочно избрала предмет своего политического влияния, который мог принести максимальные политические дивиденды в виде её поддержки со стороны широких слоёв населения. Это были предприятия торговли, общественного питания и бытового обслуживания населения. Слабо развитые, они не могли удовлетворить потребности общества. Сделано несколько принципиальных выводов относительно значения общественного контроля. Автор убеждён, что его иелью была маскировка концептуальных изъянов, заложенных в основы советской экономики. Его целью, по мнению исследователя, было также увести в тень тоталитарную сущность новой власти, тем самым порождая иллюзию её заботь об обществе. Исследователь не без оснований полагает, что организованный профсоюзами контроль за сферой торговли, питания и быта дал возможность несколько сдвинуть проблему с мёртвой точки, что на определённое время отсрочило отставку власти «оттепели». Вместе с тем, исследователь акиентирует внимание на том, что организованный профсоюзами контроль был частью кониепиии советского менеджмента. Развивая его, эта общественная организация подтверждала ленинскую 
концепцию профсоюзного движения как «икольл коммунизма», в которой обучают трудящихся управлять государственными делами.

Ключевые слова: бытовое обслуживание, общественный контроль, общественное питание, «оттепель», политическая власть, профессиональные союзы, торговля.

\section{ДЖЕРЕЛА ТА ЛІТЕРАТУРА}

1. Баран В. К., Даниленко В. М. Україна в умовах системної кризи (1946-1980-і рр. Київ : Видавничий дім Альтернативи, 1999. 308 с.

2. В Президиум ЦК КПСС. Письмо А.И. Кириченко. Центральний державний архів громадських об'єднань України (ЦДАГО України) Ф. 1, оп. 31, спр. 563.

3. Даниленко В., Лаас Н., Смольніцька М. Від пізнього сталінізму до хрущовської «відлиги». Україна XX cm.: культура, ідеологія, політика. Збірник статей. Київ: Інститут історії України НАН України, 2014. Вип. 19. С. 5-19.

4. Докашенко В. М. Радянські профспілки і контроль за діяльністю підприємств торгівлі та громадського харчування: аналіз одного профспілкового положення. Грані історії: 3б. наук. працьь. Горлівка: Вид-во ГДПІІМ, 2012. Вип. 5. С. 3-15.

5. Доклад тов. Н. С. Хрущёва «Контрольные цифры развития народного хозяйства СССР на 1959-1965 годы. Внеочередной ХХІ съезд коммунистической партии Советского Союза. 27 января - 5 февраля 1959 г. Стенографический отчёт. Т. І. Москва : Госполитиздат, 1959. С. 12-120.

6. Кількість робочих місць в торгуючих організаціях. Народне господарство Украӥнської РСР в 1964 рочүi. Статистичний щуорічник. Київ: Вид-во «Статистика», 1965. С. 542.

7. Ковпак Л. Соціально-побутові умови життя населення України в другій половині ХХ ст. (1945-2000 рр.). Київ : Ін-т історії України НАН України, 2003. $250 \mathrm{c}$.

8. Ленин В.И. Удержат ли большевики власть. Полн. собр. соч. Т. 34. С. 287-339.

9. Лист Голови Укрпрофради до ЦК Компартії України від 8 вересня 1956 р. ЦДАГО Украӥни. Ф. 1, оп. 31, спр. 330.

10. Лист Центрального Комітету КП Української РСР I Ради Міністрів Української РСР обкомам і райкомам партії, облвиконкомам і райвиконкомам, первинним партійним організаціям колгоспів і радгоспів «Про серйозні недоліки у виробництві і заготівлях м’яса та молока в колгоспах і радгоспах республіки». Квітень 1960 р. № П-8/6. ЦДАГО України. Оп. 6, спр 3101 арк. 95-100.

11. Маленков Г. М. Речь на пятой сессии Верховного Совета СССР. 8 августа 1953 года. Москва : Изд-во политической литературы, 1953.40 с. 
12. Маркс К. Критика Готской программы. К. Маркс и Ф.Энгельс. Сочинения. Издание второе. Т. 19. Москва : Госполитиздат, 1961. С. 9-32.

13. О работе профессиональных союзов СССР. Постановление Пленума ЦК КПСС. 14-17 декабря 1957 г. Коммунистическая пария Советского Союза в резолюииях и решениях съездов, конферениий и пленумов ЦК (1898-1986). Т. 9. 1956-1960. 9-е изд., доп. и испр. Москва : Политиздат, 1986. С. 212-228.

14. О дальнейшем развитии и улучшении общественного питания. Постановление ЦК КПС, Совета Министров ССCР от 20.02.1959 г. № 182. URL: www.consultant.ru

15. О контроле профсоюзов за работой оптовых баз. Директивное письмо ВЦСПС и Министерства торговли СССР центральным комитетам и советам профсоюзов, министерствам торговли союзных и автономных республик, начальникам (заведующим) краевых, областных и городских управлений (отделов) торговли от 19 сентября 1958 г. Справочник профсоюзного работника, 1957. Москва : Профиздат, 1958. С. 15.

16. О контроле профсоюзов за работой оптовых баз. Постановление Президиума ВЦСПС от 19 сентября 1958 г. Справочник профсоюзного работника, 1957. Москва : Профиздат, 1958. С. 13-14.

17. О мерах по улучшению бытового обслуживания населения. Постановление ЦК КПСС и Совета Министров CCCP от 6 марта 1959 г. URL: www.consultant.ru

18. О мерах содействия осуществлению контроля профсоюзов над работой предприятий торговли и общественного питания. Приказ Министра торговли Союза ССР от 30 сентября 1953 г. Справочник профработника, 1957. Москва : Профиздат, 1958. С. 625.

19. О работе профсоюзных организаций по выполнению Постановления ЦК КПСС и Совета Министров СССР от 1 марта 1956 года «О мероприятиях по улучшению работы предприятий общественного питания. Постановление президиума ВЦСПС от 7 апреля 1956 г. Справочник профработника, 1957. Москва : Профиздат, 1958. С. 620-624.

20. О развитии общественного питания. Постановление Совета Народных Комиссаров. 18 июля 1930 г. URL: http: istmat.info/node/49917

21. О ходе выполнения постановления ЦК КПСС и Совета Министров СССР от 6 марта 1959 года «О мерах по улучшению бытового обслуживания населения» предприятиями промышленности местного подчинения РСФСР. Центральний державний архів вищих органів влади і управління Украӥни (ЦДАВО Украӥни), Ф. 2605, оп. 8, спр. 3093.

22. Об увеличении производства, повышения качества широкого потребления и мерах по обеспечению улучшения бытового обслуживания трудящихся. Постановление Пленума ЦК Компартии Украины. 29-30 июня 1953 г. Коммунистическая партия Украины в резолюииях и решениях 
съездов, конференций и пленумов ЦК. Том второй. 1945-1976. Москва : Политиздат Украины, 1977. С. 465-478.

23. Об улучшении организации общественного питания. Постановление Совета Народных Комиссаров. 18 июля 1930 г. URL: http: istmat.info/node/ 56025

24. Отчёт о работе Кировоградского облсовпрофа о выполнении Президиума Укрсовпрофа от 27.08.1958 г. «О работе Кировоградского областного совета профессиональных союзов по выполнению решений декабрьского Пленума ЦК КПСС и IX Пленума ВЦСПС (по состоянию на 01.07.1959 г. ЦДАВО Украӥни, Ф. 2605, оп. 8, спр. 2027.

25. Підраховано за: Виробництво м'яса і сала (в забійній вазі) по категоріям господарств (тис. тон); Виробництво молока по категоріям господарств (тис. тон); Виробництво яєць по категоріям господарств (млн штук). Народне господарство Української РСР в 1964 році. Київ : Політвидав України, 1965. С. 331, 333-334.

26. Положение о комиссии общественного контроля за работой торга, треста столовых ОРСа, продснаба. Утверждено Президиумом ВЦСПС 11 июля 1958 г. Бюллетень Всесоюзного иентрального совета профессиональных союзов. 1958. № 15. С. 9-11.

27. Положение о комиссии общественного контроля и общественных контролёрах фабрично-заводского (местного) комитета профсоюза за работой предприятий торговли и общественного питания. Постановление ВЦСПС от 8 марта 1957 г. Справочник профработника. 1958. № 15. С. 628-635.

28. Похлёбкин Вильям. Весёлая кухня. Москва, 2000. URL: http//file:///C:/ Users/home/Downloads/453164-www.libfox.ru.pdf

29. Про дальший розвиток i поліпшення громадського харчування в Українській РСР. Постанова ЦК Компартії України та Ради Міністрів Української РСР. 23 березня 1959 р. Збірник постанов та розпоряджень уряду Української Радянської Соиіалістичної Республіки. № 3. 3-23 березня 1959 року. Київ : Держполітвидав УРСР, 1959. С. 3-10.

30. Продаж основних сільськогосподарських продуктів на колгоспних ринках окремих міст. Народне господарство Української РСР в 1964 ройі. C. $552-553$.

31. Пыжиков А. В. Хрущёвская «оттепель». Москва: ОЛМА-ПРЕСС, 2002. $511 \mathrm{c}$.

32. Складено на основі даних: Таблиці: «Питома вага засобів виробництва (група «А») і предметів споживання (група «Б») у валовій продукції промисловості». Народне господарство Украӥнської РСР в 1959 роиі. Статистичний щорічник. Київ: Державне статистичне видавництво, 1960. С. 56; Народне господарство Української РСР в 1961 році. Статистичний щорічник. Київ: Державне статистичне видавництво, 1962. С. 59; Народне господарство Української РСР в 1963 році. Статистичний щорічник. Київ: Державне статистичне видавництво, 1964. С. 61; Народне 
господарство Української РСР в 1964 році. Статистичний щорічник. Київ: Державне статистичне видавництво, 1965. С. 54.

33. Справка о состоянии общественного питания и бытового обслуживания в совхозах Одесского винодельческого треста. (Составлена управляющим трестом Ф. Манзиенко). ЦДАВО України, Ф. 2605, оп. 8, спр. 3098.

34. Справка о ходе выполнении решений XX съезда КПСС профсоюзными организациями Харьковской области. ЦДАВО України, Ф. 2605, оп. 8, спр. 2022.

35. Среднемесячная заработная плата по экономике Украины. URL: https://i.factor.ua/info/pension/avg-ua/

36. Сталин И. В. Экономические проблемы социализма в СССР. Москва : Госполитиздат, $1952.94 \mathrm{c}$.

37. Устав профессиональных союзов СССР. Утверждён Х съездом профсоюзов СССР (19-27 апреля 1949 г.). Москва : Профиздат, 1952. 32 с.

\section{References}

1. Baran, V. K., Danylenko, V. M. (1999), Ukraina v umovakh systemnoi kryzy (194 -1980-i rr.), Vydavnychyi dim «Alternatyva», Kyiv.

2. V Prezidium CK KPSS. Pismo A. I. Kirichenko. Centralnij derzhavnij arhiv gromadskih ob'yednan Ukrayini (CDAGO Ukrayini) F. 1, op. 31, spr. 563.

3. Danylenko, V., Laas, N., Smolnytska, M. (2014), Ukrainske suspilstvo vid piznoho stalinizmu do khrushchovskoi «vidlyhy» Ukraina KhKh st.: kultura, ideolohiia, polityka. Zbirnyk statei, Vyp. 19, Instytut istorii Ukrainy NAN Ukrainy, Kyiv, 5-19.

4. Dokashenko, V. M. Radyanski profspilki i kontrol za diyalnistyu pidpriyemstv torgivli ta gromadskogo harchuvannya: analiz odnogo profspilkovogo polozhennya. Grani istoriyi: Zb. nauk. prac. Gorlivka : Vid-vo GDPIIM, 2012. Vip. 5. 3-15.

5. Doklad tov. N. S. Hrushyova «Kontrolnye cifry razvitiya narodnogo hozyajstva SSSR na 1959-1965 gody (1959), Vneocherednoj HHI sezd kommunisticheskoj partii Sovetskogo Soyuza. 27 yanvarya - 5 fevralya 1959 g. Stenograficheskij otchyot, T. I, Gospolitizdat, Moscow, 12-120.

6. Kilkist robochih misc $\mathrm{v}$ torguyuchih organizaciyah. Narodne gospodarstvo Ukrayinskoyi RSR v 1964 roci. Statistichnij shorichnik (1965). Kyiv, Vid-vo «Statistika», 542.

7. Kovpak, L. (2003). Socialno-pobutovi umovi zhittya naselennya Ukrayini v drugij polovini HH st. (1945-2000 rr.), In-t istoriyi Ukrayini NAN Ukrayini, Kyiv.

8. Lenin, V. I. Uderzhat li bolsheviki vlast. Poln. sobr. soch., T. 34, 287-339.

9. List Golovi Ukrprofradi do CK Kompartiyi Ukrayini vid 8 veresnya 1956 r. CDAGO Ukrayini. Spr. 330.

10. List Centralnogo Komitetu KP Ukrayinskoyi RSR I Radi Ministriv Ukrayinskoyi RSR obkomam i rajkomam partiyi, oblvikonkomam i 
rajvikonkomam, pervinnim partijnim organizaciyam kolgospiv i radgospiv «Pro serjozni nedoliki $\mathrm{u}$ virobnictvi i zagotivlyah m'yasa ta moloka $\mathrm{v}$ kolgospah i radgospah respubliki». Kviten 1960 r. № P-8/6. CDAGO Ukrayini. F. 1, op. 6, spr. 3101, ark. 95-100.

11. Malenkov, G. M. (1953), Rech na pyatoj sessii Verhovnogo Soveta SSSR. 8 avgusta 1953 goda. Moscow : Izd-vo politicheskoj literatury.

12. Marks, K. (1961). Kritika Gotskoj programmy, K. Marks $i$ F. Engels. Sochineniya. Izdanie vtoroe, T. 19. Moscow : Gospolitizdat. 9-32.

13. O rabote professionalnyh soyuzov SSSR. Postanovlenie Plenuma CK KPSS. 14-17 dekabrya 1957 g. (1986). Kommunisticheskaya pariya Sovetskogo Soyuza v rezolyuciyah i resheniyah sezdov, konferencij i plenumov CK (18981986.). T. 9. 1956-1960, 9-e izd., dop. i ispr. Moscow : Politizdat, 212-228.

14. O dalnejshem razvitii i uluchshenii obshestvennogo pitaniya. Postanovlenie CK KPS, Soveta Ministrov SSSR ot 20.02.1959 g. № 182. URL: www.consultant.ru

15. O kontrole profsoyuzov za rabotoj optovyh baz. Direktivnoe pismo VCSPS i Ministerstva torgovli SSSR centralnym komitetam i sovetam profsoyuzov, ministerstvam torgovli soyuznyh i avtonomnyh respublik, nachalnikam (zaveduyushim) kraevyh, oblastnyh i gorodskih upravlenij (otdelov) torgovli ot 19 sentyabrya 1958 g. Spravochnik profsoyuznogo rabotnika (1958). Moscow : Profizdat. 15.

16. O kontrole profsoyuzov za rabotoj optovyh baz. Postanovlenie Prezidiuma VCSPS ot 19 sentyabrya 1958 g. Spravochnik profsoyuznogo rabotnika (1958). Moscow : Profizdat. 13-14.

17. O merah po uluchsheniyu bytovogo obsluzhivaniya naseleniya. Postanovlenie CK KPSS i Soveta Ministrov SSSR ot 6 marta $1959 \mathrm{~g}$. URL: www.consultant.ru

18. O merah sodejstviya osushestvleniyu kontrolya profsoyuzov nad rabotoj predpriyatij torgovli i obshestvennogo pitaniya. Prikaz Ministra torgovli Soyuza SSR ot 30 sentyabrya 1953 g. Spravochnik profsoyuznogo rabotnika (1958). Moscow : Profizdat., 625.

19. O rabote profsoyuznyh organizacij po vypolneniyu Postanovleniya CK KPSS i Soveta Ministrov SSSR ot 1 marta 1956 goda «O meropriyatiyah po uluchsheniyu raboty predpriyatij obshestvennogo pitaniya. Postanovlenie prezidiuma VCSPS ot 7 aprelya 1956 g. Spravochnik profsoyuznogo rabotnika (1958). Moscow : Profizdat. 620-624.

20. O razvitii obshestvennogo pitaniya. Postanovlenie Soveta Narodnyh Komissarov. 18 iyulya 1930 g. URL: // http: istmat.info/node/49917

21. O hode vypolneniya postanovleniya CK KPSS i Soveta Ministrov SSSR ot 6 marta 1959 goda «O merah po uluchsheniyu bytovogo obsluzhivaniya naseleniya» predpriyatiyami promyshlennosti mestnogo podchineniya RSFSR. CDAIO Ukrayini, F. 2605, vp. 8, spr. 3093. 
22. Ob uvelichenii proizvodstva, povysheniya kachestva shirokogo potrebleniya i merah po obespecheniyu uluchsheniya bytovogo obsluzhivaniya trudyashihsya. Postanovlenie Plenuma CK Kompartii Ukrainy. 29-30 iyunya 1953 g. (1977). Kommunisticheskaya partiya Ukrainy $v$ rezolyuciyah $i$ resheniyah sezdov, konferencij i plenumov CK. Tom vtoroj. 1945-1976. Moscow : Politizdat Ukrainy. S. 465-478.

23. Ob uluchshenii organizacii obshestvennogo pitaniya. Postanovlenie Soveta Narodnyh Komissarov. 18 iyulya 1930 g. URL: // http: istmat.info/node/56025

24. Otchyot o rabote Kirovogradskogo oblsovprofa o vypolnenii Prezidiuma Ukrsovprofa ot 27.08.1958 g. "O rabote Kirovogradskogo oblastnogo soveta professionalnyh soyuzov po vypolneniyu reshenij dekabrskogo Plenuma CK KPSS i IH Plenuma VCSPS (po sostoyaniyu na 01.07.1959 g. Centralnij derzhavnij arhiv vishih organiv vladi i upravlinnya Ukrayini (CDAVO Ukrayini). Spr. 2027.

25. Pidrahovano za: Virobnictvo m'yasa i sala (v zabijnij vazi) po kategoriyam gospodarstv (tis. ton); Virobnictvo moloka po kategoriyam gospodarstv (tis. ton); Virobnictvo yayec po kategoriyam gospodarstv (mln. shtuk) (1965). Narodne gospodarstvo Ukrayinskoyi RSR v 1964 roci. Kyiv : Politvidav Ukrayini. 331; 333-334.

26. Polozhenie o komissii obshestvennogo kontrolya za rabotoj torga, tresta stolovyh ORSa, prodsnaba. Utverzhdeno Prezidiumom VCSPS 11 iyulya 1958 g. (1958). Byulleten Vsesoyuznogo centralnogo soveta professionalnyh soyuzov. № 15, 9-11.

27. Polozhenie o komissii obshestvennogo kontrolya i obshestvennyh kontrolyorah fabrichno-zavodskogo (mestnogo) komiteta profsoyuza za rabotoj predpriyatij torgovli i obshestvennogo pitaniya. Postanovlenie VCSPS ot 8 marta $1957 \mathrm{~g}$. (1958). Spravochnik profrabotnika. № 15, 628-635.

28. Pohlyobkin Vilyam. Vesyolaya kuhnya (2000), Moscow. URL: http//file:///C:/ Users/home/Downloads/453164-www.libfox.ru.pdf

29. Pro dalshij rozvitok i polipshennya gromadskogo harchuvannya v Ukrayinskij RSR. Postanova CK Kompartiyi Ukrayini ta Radi Ministriv Ukrayinskoyi RSR. 23 bereznya 1959 r. Zbirnik postanov ta rozporyadzhen uryadu Ukrayinskoyi Radyanskoyi Socialistichnoyi Respubliki, (1959), № 3. 3-23 bereznya 1959 roku, Derzhpolitvidav URSR. Kyiv, 3-10.

30. Prodazh osnovnih silskogospodarskih na kolgospnih rinkah okremih mist. Narodne gospodarstvo Ukrayinskoyi RSR v 1964 roci, 552-553.

31. Pyzhikov, A. V. (2002), Hrushyovskaya «ottepel», OLMA-PRESS, Moscow.

32. Skladeno na osnovi danih: Tablici: «Pitoma vaga zasobiv virobnictva (grupa «A») i predmetiv spozhivannya (grupa «B») u valovij produkciyi promislovosti» (1960), Narodne gospodarstvo Ukrayinskoyi RSR v 1959 roci. Statistichnij shorichnik, Derzhavne statistichne vidavnictvo, Kyiv, S. 56; Narodne gospodarstvo Ukrayinskoyi RSR v 1961 roci. Statistichnij shorichnik, Derzhavne statistichne vidavnictvo, Kyiv (1962), S. 59; Narodne gospodarstvo 
Ukrayinskoyi RSR v 1963 roci. Statistichnij shorichnik, Derzhavne statistichne vidavnictvo, Kyiv (1964), S. 61; Narodne gospodarstvo Ukrayinskoyi RSR v 1964 roci. Statistichnij shorichnik, Derzhavne statistichne vidavnictvo, Kyiv (1965), 54.

33. Spravka o sostoyanii obshestvennogo pitaniya i bytovogo obsluzhivaniya $\mathrm{v}$ sovhozah Odesskogo vinodelcheskogo tresta. (Sostavlena upravlyayushim trestom F. Manzienko). CDAVO Ukrayini. F. 2605, op. 8, Spr. 3098.

34. Spravka o hode vypolnenii reshenij HH sezda KPSS profsoyuznymi organizaciyami Harkovskoj oblasti. CDAVO Ukrayini. F. 2605, op. 8, spr. 2022.

35. Srednemesyachnaya zarabotnaya plata po ekonomike Ukrainy. URL: https://i.factor.ua/info/pension/avg-ua/

36. Stalin, J. V. (1952). Ekonomicheskie problemy socializma v SSSR, Gospolitizdat, Moscow.

37. Ustav professionalnyh soyuzov SSSR (1952), Utverzhdyon X sezdom profsoyuzov SSSR (19-27 aprelya 1949 g.), Profizda.

УДК 622.276(477.75)»1954»:33.012.8-045.45

\section{НАФТОГАЗОВИЙ КОМПЛЕКС КРИМУ ТА ІНТЕГРАЦІЯ ПІВОСТРОВА В ЕКОНОМІЧНУ СИСТЕМУ УРСР У 1954 Р.}

\section{Сацький Павло}

У статті на основі архівних матеріалів здійснено дослідження інституиійного забезпечення $і$ основних етапів та особливостей розвитку нафтогазового комплексу Кримської області у період після Другої світової війни та у 1954 р. Метою статті є комплексний аналіз політики СРСР у формуванні інституцій, які здійснювали освоєння родовищ нафти $i$ газу в Криму та основних напрямів їх діяльності, а також змін у підходах до подальшого розвитку нафтогазового комплексу Кримського півострова після його включення до складу УРСР 1954 . Автором у процесі дослідження застосовано як проблемно-хронологічний метод, так і методику системного аналізу. У результаті здійсненого дослідження автором встановлено, що структура інституиійного забезпечення нафтогазового комплексу Кримської області у період ї̈ перебування в складі РСФРР не давала змоги для ефективного освоєння ресурсів півострова. Розвиток нафтогазової галузі в Криму для Ради Міністрів РСФРР і профільних інституиій Союзного Уряду не мав вагомого значення. Також, розвідку перспективних нафтових $i$ газових родовищ у Криму було зосереджено на Керченському півострові. Передача Кримської області до складу УРСР 1954 р. закладає можливості для зміни інституиійної бази розвитку нафтогазового комплексу в Криму, 